\title{
Physicochemical parameters and lactic acid bacteria count during ripening of Brazilian regional cheese manufactured with the addition of autochthonous cultures
}

\author{
Marilde Canton BRANDIELLI ${ }^{1}$, Vânia Cássia Fonseca BURGARDT ${ }^{1}$, Elisabete Hiromi HASHIMOTO ${ }^{1}$, \\ Ivane Benedetti TONIAL ${ }^{1}$, Adriana ZEMIANI ${ }^{2}$, Alessandra Furtado SILVA ${ }^{2}$, Sheila Regina ORO ${ }^{3}$, \\ João Francisco MARCHI ${ }^{4}$, Andréa Cátia Leal BADARÓ ${ }^{4}$, Fabiane Picinin CASTRO-CISLAGHI* (D), \\ Alessandra MACHADO-LUNKES ${ }^{1}$
}

\begin{abstract}
The physicochemical analyses and quantification of lactic acid bacteria of cheeses made from autochthonous lactic cultures were evaluated during ripening. There was a decrease in water activity, $\mathrm{pH}$ and moisture, and an increase in acidity, total solids, proteolysis, lipids, fat in dry matter and ash. The major fatty acids identified were palmitic, oleic, stearic and myristic acid. Lactobacillus bulgaricus and Streptococcus thermophilus presented a higher count at the beginning of ripening. The color, cohesiveness, springiness and chewiness parameters were affected by the chemical properties, which was not observed for hardness and shear force.
\end{abstract}

Keywords: pasteurized milk cheese; proteolysis; texture; color.

Practical Application: characteristics of regional cheese manufactured with autochthonous cultures.

\section{Introduction}

Cheese is a product manufactured on all continents, and Europe is the largest producer and consumer with America being the second largest world market (Food and Agriculture Organization, 2016; Johnson, 2017). A large variety of cheeses exist worldwide, which can be categorized based on several properties such as type of milk used, manufacturing specificities, texture, ripening time, among others. Cheeses may also be classified based on their producing region, which carries the influence of the local environment on cheese properties (Kamimura et al., 2019).

The promotion of regional products is an important strategy that assists in rural development, besides enriching the culture of a region, retracing the history of the product and the different generations of producers (González-Córdova et al., 2016). In this context, European countries are those that most promote the production and consumption of regional cheese (Câmara et al., 2017). In Brazil, regional cheeses crafted by hand are known in different states, where Minas Gerais stands out for being the principal regional cheese producing state (Sant'Anna et al., 2017). The most famous and valued cheeses manufactured in Minas Gerais are the Canastra and Serro cheeses, with distinct flavors and historical characteristics, being the Brazilian cheeses with Geographical Indications. Still, state of Minas Gerais produces Serra do Salitre, Alto Parnaíba or Cerrado cheese and Araxá cheese. In the North-East there is Manteiga cheese and Coalho cheese, and in the south of Brazil, Serrano and Colonial cheeses are produced (Castro-Cislaghi \& Badaró, 2019; Kamimura et al., 2019).
With sights on regional enhancement and growth of South-West Paraná, a typical mature cheese was developed through a partnership between Brazil and Italy. This cheese uses raw cow's milk or pasteurized milk and is produced with autochthonous lactic culture of selected microorganisms from the milk of regional producers (Todescatto, 2014; Pereira et al., 2017). Thus, the lactic cultures used from the region were among the agents that bestowed specific characteristics on this Brazilian cheese. In fact, the lactic cultures have a principal function of metabolism of lactose for the production of lactic acid, besides producing flavor compounds, antimicrobial substances and breaking down milk proteins, particularly during cheese ripening (Pedersen et al., 2016).

The ripening process promotes physicochemical, biochemical and microbiological alterations which lead to transformations in texture and color and principally in sensory characteristics through the formation of typical cheese flavors and aromas (McSweeney, 2004). According to sensory studies (data not shown), during the ripening process the regional cheese was yellow in color, with acidic, salty and lactic flavor characteristics, an acidic odor of cooked milk, a fatty texture and hardness that altered over ripening.

In order to gather knowledge in respect to Brazilian regional cheese characteristics during ripening, this work aims to evaluate the behavior of lactic acid bacteria, chemical composition, proteolysis, fatty acids profile, color and textural parameters for 120 days. 


\section{Materials and methods}

\subsection{Autochthonous starter cultures}

The autochthonous strains were provided by Bioagro Societá Partecipata de Veneto Agricoltura, Italy. They were isolated from milk obtained in the South-West of Paraná, Brazil. The strains were characterized from a technological viewpoint (acidifying activity) and their identity was confirmed by use genetic techniques. Two different lyophilized autochthonous starter cultures were used, due to the industrial issue of culture rotation. Autochthonous starter culture A was composed of strains of Streptococcus thermophilus ST28 and ST128 and strains of Lactobacillus delbrueckii sp. bulgaricus LB134. Starter culture B was composed of the same microorganisms, but the strains of Streptococcus thermophilus were different (ST98 and ST104) (Pereira et al., 2017).

\subsection{Manufacture and ripening of Brazilian regional cheese}

The cheese, denominated Santo Giorno, was manufactured at a dairy in South-West Paraná, following the production process foreseen by Pereira et al. (2017). The pasteurized milk was divided in two aliquots of 1,800 liters each. One batch of cheese was produced with autochthonous culture A (CA) and another batch with autochthonous culture B (CB). The lysozyme $\left(2 \mathrm{~g} 100 \mathrm{~L}^{-1}\right)$ was added and stirred constantly for 10 minutes. Milk coagulation was achieved by adding chymosin (powdered form, strength of $1: 100,000)\left(4 \mathrm{~g} 100 \mathrm{~L}^{-1}\right)$. After 22 to 25 minutes of rest (at $35-37^{\circ} \mathrm{C}$ ), the curd was cut (size of a corn grain), and stirred for 10 minutes. The curd was indirectly heated until $44^{\circ} \mathrm{C}$ and stirred for 15-30 minutes. Then, it was placed in cylindrical moulds ( $10 \mathrm{~cm}$ high by $25 \mathrm{~cm}$ in diameter), pressed twice for 15 minutes ( 3 bar), turned every half hour until pH 5.20, and then placed in cold storage at $5{ }^{\circ} \mathrm{C}$ for 12 hours. The cheeses were salted in brine $\left(20 \%\right.$; pH $\left.5.25 ; 10-12^{\circ} \mathrm{C}\right)$ for 36 hours. Finally, the cheeses were ripened at 6 to $8{ }^{\circ} \mathrm{C}$ and $85 \%$ of relative humidity for the first 30 days. Then the temperature was maintained at 10 to $12{ }^{\circ} \mathrm{C}$ and relative humidity of 82 to $85 \%$. After 37 days of ripening the cheeses received a polymer coating of polyvinyl acetate (GlobalSystem Coat Incolor). The final weight was approximately $5 \mathrm{~kg}$. The cheeses were evaluated at 0,60 and 120 days of ripening.

\subsection{Physicochemical analysis}

The cheeses were analyzed as to acidity (g $100 \mathrm{~g}^{-1}$ lactic acid), moisture, total solids, proteins, lipids, ash and total carbohydrate obtained by difference (Association of Official Analytical Chemists, 2005). Water activity was determined using Labmaster equipment (Novasina AG, Lachen, Switzerland) at a temperature of $25^{\circ} \mathrm{C}$. The $\mathrm{pH}$ was measured with $\mathrm{pH}$ meter TEC-5 (Tecnal, Piracicaba, Brazil). Fat in dry matter concentration was calculated as fat/total dry matter and expressed as a percentage. The concentration of sodium, potassium and calcium were obtained from the ash following the method described by Cichoscki et al. (2002). The analyses were performed in an atomic absorption spectrometer with flame atomization (SOLAAR S4, Thermo Scientific, USA) equipped with deuterium background correction and hollow cathode lamp. The absorbances were measured at 589.0, 766.5 and $422.7 \mathrm{~nm}$, for the sodium, potassium and calcium, respectively.

\subsection{Proteolysis}

The total nitrogen (TN), soluble nitrogen at pH 4.6 (SN-pH 4.6) and $12 \%(\mathrm{w} / \mathrm{v})$ trichloroacetic acid (SN-TCA) content were determined by Kjeldahl method. The water-soluble fraction of samples was carried out with sodium citrate solution $0.5 \mathrm{~mol} \mathrm{~mL}$. After, it was fractioned for determination of SN-pH 4.6 and SN-TCA. The proteolysis evaluation was performed through the extent of proteolysis index (EPI) and the depth of proteolysis index (DPI), EPI being calculated by division of the result of SN-pH 4.6 by the total nitrogen (TN) value. To calculate DPI, SN-TCA divided by the TN value was used (Garcia et al., 2009).

\subsection{Counts of lactic acid bacteria}

Lactobacillus delbrueckii sp. bulgaricus were quantified in MRS (de Man, Rogosa and Sharpe) agar acidified at pH 5.4 using glacial acetic acid, it being incubated at $37^{\circ} \mathrm{C}$ for $72 \mathrm{hr}$, in anaerobic conditions. For quantification of Streptococcus thermophilus the agar used was M17 agar under aerobic conditions and incubated at $37^{\circ} \mathrm{C}$ for $48 \mathrm{hr}$. The counts were expressed as log colony-forming units per gram of cheese $\left(\log \mathrm{cfu} \mathrm{g}^{-1}\right)$ (American Public Health Association, 2004).

\subsection{Fatty acids profile}

Fatty acid methyl esters (FAME) were analysed using a gas chromatograph 2010 Plus (Shimadzu, Japan), equipped with flame ionization detector and fused silica capillary column (Supelco, $100 \mathrm{~m}, 0.25 \mathrm{~mm}$ and $0.20 \mu \mathrm{m}$ of cyanopropyl polysiloxane). The gas flux (White Martins) was $1.12 \mathrm{~mL} \mathrm{~min}^{-1}$ for the carrier gas $(\mathrm{He}), 40 \mathrm{~mL} \mathrm{~min}^{-1}$ for $\mathrm{H}_{2}$ and $400 \mathrm{~mL} \mathrm{~min}^{-1}$ for the flame synthetic air. The outlet signal from the detector was integrated using Shimadzu GC solution software. The FAME were identified by comparison with the retention times of standards from Sigma 189-19 (St. Louis, MO, USA) and was expressed as the weight percentage of each fatty acid relative to the total fatty acids (\%). The Atherogenic (AI) and Thrombogenic Indexes (TI) were also calculated by mathematical equations: $\mathrm{AI}=(\mathrm{C} 12: 0+4 \mathrm{C} 14: 0+\mathrm{C} 16: 0) /\left[\sum \mathrm{MUFA}+\sum \mathrm{PUFA}(\mathrm{n}-6)\right.$ and $(\mathrm{n}-3) ;$ $\mathrm{TI}=(\mathrm{C} 14: 0+\mathrm{C} 16: 0+\mathrm{C} 18: 0) /\left[0.5 \sum \mathrm{MUFA}+0.5 \sum \mathrm{PUFA}(\mathrm{n}-6)\right.$ $\left.+3 \sum \operatorname{PUFA}(n-3)+(n-3) /(n-6)\right]($ Batista et al., 2017).

\subsection{Physical analyses}

The colour parameters $\mathrm{L}^{*}$ (lightness), $\mathrm{a}^{\star}$ (red-green axis) and $\mathrm{b}^{\star}$ (yellow-blue axis) were determined by using a colourimeter Minolta Chroma Meter CR-400/410 (Konica Minolta, Osaka, Japan). A standard ceramic white was used as a blank. Four measurements were taken in different points of a $35 \mathrm{~mm}$ cylinder of cheese.

Texture profile analysis (TPA) was evaluated by TA.XT Plus texture analyzer (Stable Micro Systems, Godalming, UK) using an aluminum cylindrical probe $\mathrm{P} / 40$, and a double bite compression cycle. Hardness, cohesiveness, springiness and chewiness were analyzed. Samples were cut into cylindrical specimens 
of $20 \mathrm{~mm}$ height and $35 \mathrm{~mm}$ diameter. The deformation curve over time was obtained with a compression speed of $4 \mathrm{~mm} \mathrm{~s}^{-1}$ and pressure $0.1 \mathrm{~N}$. Measurements were conducted in twelve repeats (six on each duplicate sample). The cutting-shear test was performed using a probe HDP/VB. Cheese samples were cut into $20 \times 10 \times 10 \mathrm{~mm}$ cubes. The test adopted the following parameters: pre-test speed $\left(1.0 \mathrm{~mm} \mathrm{~s}^{-1}\right)$, test speed $\left(2.0 \mathrm{~mm} \mathrm{~s}^{-1}\right)$, post-test speed $\left(10.0 \mathrm{~mm} \mathrm{~s}^{-1}\right)$, distance $(30 \mathrm{~mm})$ and applied force $(5 \mathrm{~g})$.

\subsection{Statistical analysis}

The data were analyzed using STATISTICA 7.0 software (Statsoft Inc., Tulsa, OK, USA). The statistical analysis between $\mathrm{CA}$ and $\mathrm{CB}$ cheeses, considering the same ripening period, was performed through comparison for independent samples t-test. The effect of ripening periods of cheeses was analysed using the one-way analysis of variance (ANOVA) and Tukey test. The results were expressed as mean \pm standard deviation. For data which did not fulfil the assumption of variance normality and homogeneity, non-parametric tests were applied, using XLSTAT 2016 software (Addinsoft, Paris, France). Besides, XLSTAT 2016 software was used to determine the Pearson correlation for relationships between physical and chemical parameters of cheese.

\section{Results and discussion}

\subsection{Physicochemical analysis}

The results obtained during the ripening period of the Brazilian regional cheese are shown in Table 1 . There was non-significant difference in water activity and $\mathrm{pH}$ between $\mathrm{CA}$ and $\mathrm{CB}$, at respective ripening periods evaluated $(\mathrm{p}>0.05)$. On the other hand, the ripening of the cheeses led to a decrease in the water activity and the $\mathrm{pH}$. This decrease in water activity could be due to the salting process, the loss of water by evaporation, proteolysis and lipolysis (Beresford et al., 2001). During the ripening water activity may decrease to values near to 0.917 , lower than the optimal requirements of starter bacteria. The $\mathrm{pH}$ decrease in

Table 1. Chemical parameters of the Brazilian regional cheese during the ripening.

\begin{tabular}{|c|c|c|c|c|}
\hline \multirow{2}{*}{ Parameters } & \multirow{2}{*}{ Sample } & \multicolumn{3}{|c|}{ Ripening period (days)* } \\
\hline & & 0 & 60 & 120 \\
\hline \multirow[t]{2}{*}{ Water activity } & CA & $0.95 \pm 0.01^{\mathrm{aA}}$ & $0.93 \pm 0.00^{\mathrm{aB}}$ & $0.92 \pm 0.01^{\mathrm{aC}}$ \\
\hline & $\mathrm{CB}$ & $0.95 \pm 0.00^{\mathrm{aA}}$ & $0.93 \pm 0.00^{\mathrm{aB}}$ & $0.91 \pm 0.01^{\mathrm{aC}}$ \\
\hline \multirow[t]{2}{*}{$\mathrm{pH}$} & CA & $5.70 \pm 0.10^{\mathrm{aA}}$ & $5.49 \pm 0.06^{\mathrm{aB}}$ & $5.41 \pm 0.21^{\mathrm{aB}}$ \\
\hline & $\mathrm{CB}$ & $5.57 \pm 0.04^{\mathrm{aA}}$ & $5.49 \pm 0.01^{\mathrm{aAB}}$ & $5.41 \pm 0.06^{\mathrm{aB}}$ \\
\hline \multirow[t]{2}{*}{ Acidity (g $100 \mathrm{~g}^{-1}$ lactic acid) } & CA & $0.33 \pm 0.02^{\mathrm{bC}}$ & $0.70 \pm 0.00^{\mathrm{bB}}$ & $0.91 \pm 0.13^{\mathrm{aA}}$ \\
\hline & $\mathrm{CB}$ & $0.43 \pm 0.01^{\mathrm{aC}}$ & $0.72 \pm 0.01^{\mathrm{aB}}$ & $0.98 \pm 0.05^{\mathrm{aA}}$ \\
\hline \multirow[t]{2}{*}{ Moisture (g $100 \mathrm{~g}^{-1}$ ) } & CA & $45.12 \pm 0.34^{\mathrm{bA}}$ & $41.49 \pm 1.06^{\mathrm{aB}}$ & $37.85 \pm 1.89^{\mathrm{aC}}$ \\
\hline & $\mathrm{CB}$ & $46.44 \pm 0.31^{\mathrm{aA}}$ & $42.04 \pm 0.89^{\mathrm{aB}}$ & $39.32 \pm 0.76^{\mathrm{aC}}$ \\
\hline \multirow[t]{2}{*}{ Total solids (g $100 \mathrm{~g}^{-1}$ ) } & CA & $54.88 \pm 0.34^{\mathrm{aC}}$ & $58.51 \pm 1.06^{\mathrm{aB}}$ & $62.15 \pm 1.89^{\mathrm{aA}}$ \\
\hline & $\mathrm{CB}$ & $53.56 \pm 0.31^{\mathrm{bC}}$ & $57.96 \pm 0.89^{\mathrm{aB}}$ & $60.68 \pm 0.76^{\mathrm{aA}}$ \\
\hline \multirow[t]{2}{*}{ Total protein $\left({\left.\mathrm{g} 100 \mathrm{~g}^{-1}\right)}\right.$} & CA & $21.15 \pm 0.17^{\mathrm{aC}}$ & $22.02 \pm 0.32^{\mathrm{aB}}$ & $23.55 \pm 0.26^{\mathrm{aA}}$ \\
\hline & $\mathrm{CB}$ & $21.75 \pm 0.37^{\mathrm{aC}}$ & $22.18 \pm 0.12^{\mathrm{aB}}$ & $24.09 \pm 0.93^{\mathrm{aA}}$ \\
\hline \multirow[t]{2}{*}{ Fat $\left(\mathrm{g} 100 \mathrm{~g}^{-1}\right)$} & CA & $25.07 \pm 0.31^{\mathrm{aB}}$ & $26.34 \pm 1.11^{\mathrm{aA}}$ & $28.11 \pm 1.53^{\mathrm{aA}}$ \\
\hline & $\mathrm{CB}$ & $23.68 \pm 1.14^{\mathrm{aB}}$ & $25.61 \pm 0.44^{\mathrm{aAB}}$ & $27.13 \pm 0.67^{\mathrm{aA}}$ \\
\hline \multirow[t]{2}{*}{ Fat in Dry Matter (g $\left.100 \mathrm{~g}^{-1}\right)$} & CA & $45.02 \pm 1.38^{\mathrm{aA}}$ & $45.01 \pm 1.13^{\mathrm{aA}}$ & $45.27 \pm 3.16^{\mathrm{aA}}$ \\
\hline & $\mathrm{CB}$ & $44.20 \pm 1.94^{\mathrm{aA}}$ & $44.18 \pm 0.13^{\mathrm{aA}}$ & $44.71 \pm 0.85^{\mathrm{aA}}$ \\
\hline \multirow[t]{2}{*}{ Carbohydrates (g $100 \mathrm{~g}^{-1}$ ) } & CA & $4.41 \pm 0.56^{\mathrm{aA}}$ & $5.11 \pm 0.36^{\mathrm{aA}}$ & $4.86 \pm 2.30^{\mathrm{aA}}$ \\
\hline & $\mathrm{CB}$ & $4.03 \pm 1.01^{\mathrm{aA}}$ & $5.17 \pm 0.45^{\mathrm{aA}}$ & $3.98 \pm 0.84^{\mathrm{aA}}$ \\
\hline \multirow[t]{2}{*}{ Ash $\left(\mathrm{g} 100 \mathrm{~g}^{-1}\right)$} & $\mathrm{CA}$ & $4.25 \pm 0.26^{\mathrm{aB}}$ & $5.04 \pm 0.15^{\mathrm{aA}}$ & $5.64 \pm 0.29^{\mathrm{aA}}$ \\
\hline & $\mathrm{CB}$ & $4.11 \pm 0.11^{\mathrm{aC}}$ & $5.00 \pm 0.06^{\mathrm{aB}}$ & $5.47 \pm 0.17^{\mathrm{aA}}$ \\
\hline \multirow[t]{2}{*}{ Sodium (g $\left.100 \mathrm{~g}^{-1}\right)$} & CA & $1.34 \pm 0.16^{\mathrm{aB}}$ & $1.92 \pm 0.11^{\mathrm{aA}}$ & $1.69 \pm 0.15^{\mathrm{aAB}}$ \\
\hline & $\mathrm{CB}$ & $1.32 \pm 0.07^{\mathrm{aB}}$ & $1.95 \pm 0.05^{\mathrm{aA}}$ & $1.79 \pm 0.21^{\mathrm{aA}}$ \\
\hline \multirow[t]{2}{*}{ Potassium (g $100 \mathrm{~g}^{-1}$ ) } & CA & $0.58 \pm 0.01^{\mathrm{bC}}$ & $0.81 \pm 0.01^{\mathrm{aA}}$ & $0.74 \pm 0.03^{\mathrm{aB}}$ \\
\hline & $\mathrm{CB}$ & $0.66 \pm 0.01^{\mathrm{aA}}$ & $0.87 \pm 0.03^{\mathrm{aA}}$ & $0.82 \pm 0.07^{\mathrm{aA}}$ \\
\hline \multirow[t]{2}{*}{ Calcium (g $100 \mathrm{~g}^{-1}$ ) } & CA & $0.97 \pm 0.02^{\mathrm{aA}}$ & $0.97 \pm 0.07^{\mathrm{aA}}$ & $0.95 \pm 0.05^{\mathrm{aA}}$ \\
\hline & $\mathrm{CB}$ & $0.87 \pm 0.02^{\mathrm{bA}}$ & $1.11 \pm 0.16^{\mathrm{aA}}$ & $0.93 \pm 0.03^{\mathrm{aA}}$ \\
\hline \multirow[t]{2}{*}{$\%$ EPI } & $\mathrm{CA}$ & $7.79 \pm 0.49^{\mathrm{aA}}$ & $15.73 \pm 0.39^{\mathrm{aB}}$ & $19.35 \pm 3.59^{\mathrm{aB}}$ \\
\hline & $\mathrm{CB}$ & $7.90 \pm 0.64^{\mathrm{aA}}$ & $17.21 \pm 0.57^{\mathrm{bB}}$ & $19.63 \pm 1.66^{\mathrm{aB}}$ \\
\hline \multirow[t]{2}{*}{$\%$ DPI } & CA & $3.18 \pm 0.86^{\mathrm{aA}}$ & $6.86 \pm 0.94^{\mathrm{aB}}$ & $8.85 \pm 0.65^{\mathrm{aB}}$ \\
\hline & $\mathrm{CB}$ & $1.18 \pm 0.64^{\mathrm{bA}}$ & $6.73 \pm 0.88^{\mathrm{aB}}$ & $9.68 \pm 1.06^{\mathrm{aC}}$ \\
\hline
\end{tabular}

${ }^{*}$ Results expressed as mean of three replications \pm standard deviation $(\mathrm{n}=9)$. Values with different letters are significantly different $(\mathrm{P}<0.05)$. Lowercase letters in the same column $=$ differences between samples in the same ripening period (Test $\mathrm{t})$. Capital letters in the same row $=$ differences during ripening $($ Tukey test $)$. CA $=$ cheese with autochthonous culture A; CB = cheese with autochthonous culture B; EPI = Extent of Proteolysis Index; DPI = Depth of Proteolysis Index. 
the initial ripening of the cheeses occurs due to lactic acid formation from the lactose. Generally, the $\mathrm{pH}$ value is near to 5.0 and depends on the cheese variety. At 60 days of ripening, $\mathrm{CA}$ and $\mathrm{CB}$ shown similar $\mathrm{pH}$ values to Brazilian Prato cheese (Cichoscki et al., 2002).

The CA and CB showed significant increase $(\mathrm{p}<0.05)$ in acidity during the ripening, similar to other studies (Bontinis et al., 2008; Vasek et al., 2013). At 0 and 60 days of ripening, CA exhibited lower acidity values than CB. Therefore, the starter culture $\mathrm{B}$ may have metabolized a greater quantity of lactose into lactic acid. The Brazilian regional cheese shown acidity inferior to that of Prato cheese and Serrano cheese at 60 days of ripening (1.66 and $1.20 \mathrm{~g}$ of lactic acid $100 \mathrm{~g}^{-1}$, respectively), regardless of the type of starter culture and ripening period (Cichoscki et al., 2002).

No differences in total protein, lipids, fat in dry matter, carbohydrates and ash were found between cheeses during ripening. The CA and CB presented differences $(\mathrm{p}<0.05)$ for moisture and total solids only at the beginning of ripening. There was a reduction in the moisture of the cheeses, similar to previous studies on Brazilian cheese of South-West Paraná (Todescatto, 2014; Roncatti, 2016). This fact promotes an increase in the content of total solids, ash, lipids and protein. Brazilian cheese is classified as cheese of average moisture (semi-hard) (Brasil, 1996). Based on Fat in Dry Matter (FDM) content, the $\mathrm{CA}$ was classified as full-fat and the $\mathrm{CB}$ as medium-fat, at the three periods of ripening (Brasil, 1996; Food and Agriculture Organization, 2011). However, CB presented values close to the minimum limit to be considered a full-fat cheese ( 45.0 to $59.9 \%$ FDM) (Brasil, 1996).

The mineral results of $\mathrm{CA}$ and $\mathrm{CB}$ was different for potassium and calcium contents at 0 days of ripening. The sodium content of cheeses increased only in the first 60 days of ripening $(\mathrm{p}<0.05)$, possibly due to the diffusion of sodium of surface area to the interior, where the concentration is lower. This increase of sodium concentration may also occur through the loss of moisture of the product. The calcium and potassium contents did not decrease during ripening, contrary to that observed by Bontinis et al. (2008).

\subsection{Proteolysis evaluation}

As expected, during ripening there was an increase in extent of proteolysis index (EPI) for both cheeses (Table 1). This fact may be related to the action of residual coagulant enzymes, since there is no strong action of the starter culture in the primary proteolysis of the cheeses (McSweeney, 2004). CB showed higher percentages than CA only at 60 days. The EPI results of the Brazilian cheese at 120 days of ripening were similar to those obtained by Wolf et al. (2010) for Argentinean Reggianito cheese.

During the ripening period there was an increase in the depth of proteolysis index (DPI) of CA and CB cheeses (Table 1). A significant difference between the cheeses was only observed at 0 days, which can be attributed to the action of the starter cultures (McSweeney, 2004). The Brazilian regional cheese showed DPI similar to Parmesan cheese at 60 days and 120 days of ripening (Barros et al., 2011).

\subsection{Counts of lactic acid bacteria}

$\mathrm{CA}$ and $\mathrm{CB}$ cheeses showed higher counts of $S$. thermophilus $\left(9.27 \pm 1.26\right.$ and $8.82 \pm 1.03 \log \mathrm{CFU} \mathrm{g}^{-1}$, respectively) in comparison to L. bulgaricus (5.90 \pm 0.32 and $5.49 \pm 0.04 \log \mathrm{CFU} \mathrm{g}^{-1}$, respectively), which was expected, due to the proportion of microorganisms present in the starter cultures $(2: 1 \mathrm{St}: \mathrm{Lb})$. At the end of the ripening, $\mathrm{CA}$ and $\mathrm{CB}$ showed a significant decrease in the counts of S. thermophilus (5.61 \pm 0.66 and $6.64 \pm 0.04 \log \mathrm{CFU} \mathrm{g}^{-1}$, respectively) and L. bulgaricus (6.51 \pm 0.10 and $6.82 \pm 0.25 \log \mathrm{CFU} \mathrm{g}^{-1}$, respectively), which may be correlated with the increase in acidity (Table 1). L. bulgaricus and S. thermophilus grow in symbiosis. In fact, $S$. thermophilus rapidly produces lactic acid during fermentation, when associated with L. bulgaricus. However, S. thermophilus is gradually inhibited as the quantity of lactic acid increases. The reduction in water activity from 0.95 to 0.91 during ripening could be contributed to the decrease in the S. thermophilus and L. bulgaricus counts after 60 days, as $S$. thermophilus grows better in water activity above 0.98 (Tamime, 2006).

\subsection{Fatty acids profile}

Thirty-two different fatty acids were identified in the Brazilian cheeses at the three stages of ripening (Figure 1). The main fatty acids in both cheeses were myristic (C14:0), palmitic (C16:0), stearic $(\mathrm{C} 18: 0)$ and oleic acid $(\mathrm{C} 18: \ln 9 \mathrm{c})$. These fatty acids are also present in higher quantities in cow milk and its cheese products (Wolf et al., 2010). CB showed higher content of palmitic acid, while stearic and oleic acid were the most abundant fatty acid in CA at 60 and 120 days. These long-chain fatty acids (myristic, palmitic and stearic) seems to have little effect on the flavor of the cheeses. Short- and medium-chain fatty acids were higher in $\mathrm{CB}$ and there was an increase during ripening. However, the short-chain fatty acids, responsible for the strong and spicy flavour on cheeses, were not identified in high concentrations in the Brazilian cheese. In general, the main fatty acids are saturated acids, due to the use of cow milk, which is rich in this type of fatty acid.

Brazilian regional cheeses showed low values for lipid quality indices. The samples exhibited Atherogenicity Index (AI) values around $0.66(\mathrm{CA})$ and $0.64(\mathrm{CB})(\mathrm{p}<0.05)$. No differences in Thrombogenicity Index (TI) were found between cheeses and ripening with value of 0.97 (CA) and 0.94 (CB). Sperry et al. (2018) found higher AI (1.88-1.89) and TI (2.15-2.25) values in conventional and probiotic Minas Frescal cheeses. For AI and TI, there are no recommended values, but low values show a better relationship between acids that are beneficial to health such as monounsaturated fatty acids (MUFA) and polyunsaturated fatty acids (PUFA), and can prevent coronary disease (Turan et al., 2007; Tonial et al., 2011). It is true that the fatty acid profile of cheeses has a large amount of saturated fatty acids (C14:0; C16:0; C18:0), but there is also a considerable amount of MUFA (C18:1n-9) that added to PUFA contributes the low values of AI and TI.

\subsection{Physical analysis}

Lightness $\mathrm{L}^{*}$ value for the CA cheese was higher than for $\mathrm{CB}$ at the beginning of ripening. During ripening, the $\mathrm{L}^{*}$ values for $\mathrm{CA}$ and $\mathrm{CB}$ was $5 \%$ lower than previous measure at 60 days 


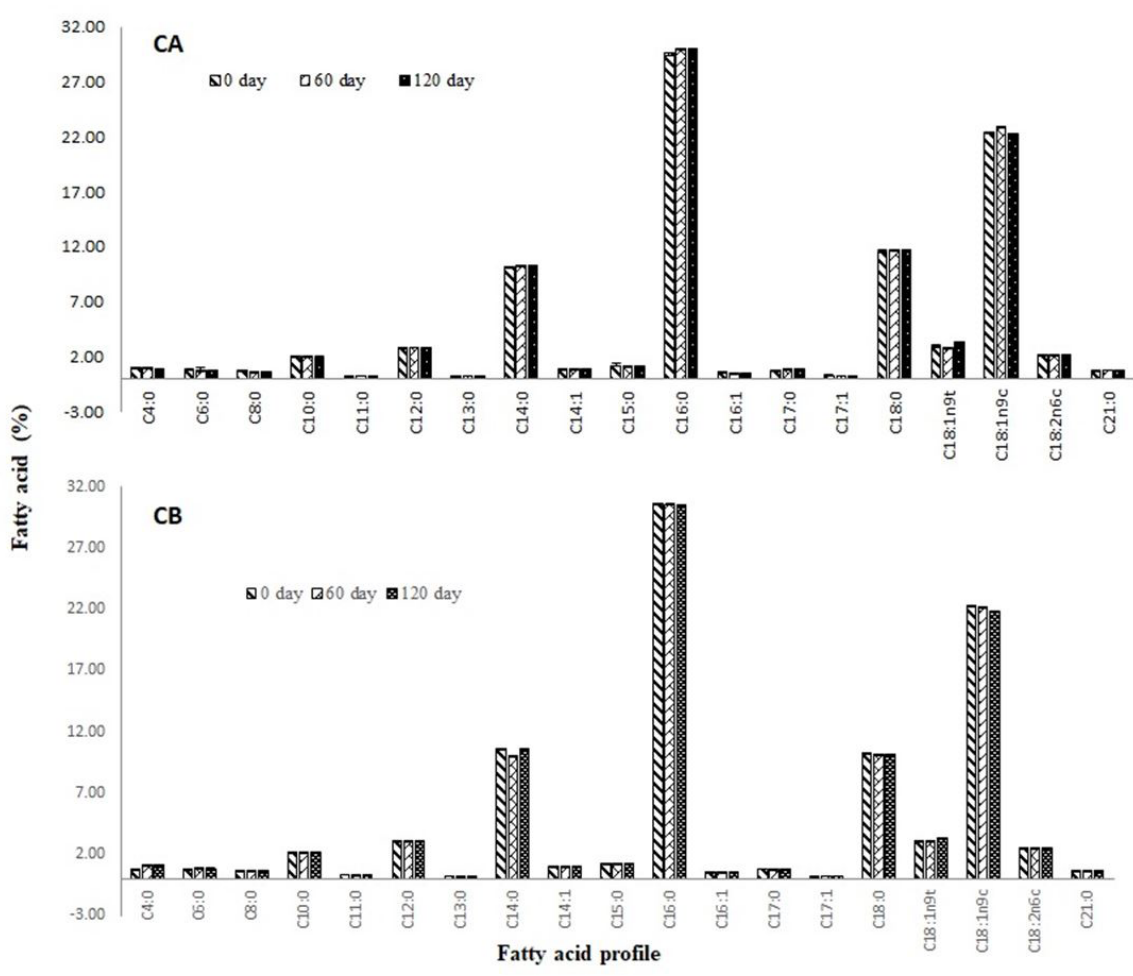

Figure 1. Levels of individual fatty acid profile of Brazilian regional cheese during the ripening. Results expressed as mean of two replications \pm standard deviation $(n=2)$. CA = cheese with autochthonous culture $A ; C B=$ cheese with autochthonous culture $B$.

Table 2. Physical parameters of the Brazilian regional cheese during the ripening.

\begin{tabular}{|c|c|c|c|c|}
\hline \multirow{2}{*}{ Parameters } & \multirow{2}{*}{ Sample } & \multicolumn{3}{|c|}{ Ripening period (days)* } \\
\hline & & 0 & 60 & 120 \\
\hline \multirow[t]{2}{*}{$\mathrm{L}^{*}$} & $\mathrm{CA}$ & $84.54 \pm 0.13^{\mathrm{aA}}$ & $80.19 \pm 0.81^{\mathrm{aB}}$ & $78.73 \pm 1.10^{\mathrm{aB}}$ \\
\hline & $\mathrm{CB}$ & $83.49 \pm 0.50^{\mathrm{bA}}$ & $80.61 \pm 0.58^{\mathrm{aB}}$ & $79.99 \pm 0.60^{\mathrm{aB}}$ \\
\hline$a^{*}$ & $\mathrm{CB}$ & $2.08 \pm 0.06^{\mathrm{aB}}$ & $3.38 \pm 0.06^{\mathrm{aA}}$ & $3.48 \pm 0.03^{\mathrm{bA}}$ \\
\hline $\mathrm{b}^{*}$ & $\mathrm{CA}$ & $20.26 \pm 0.30^{\mathrm{aA}}$ & $22.58 \pm 1.82^{\mathrm{aA}}$ & $23.71 \pm 0.44^{\mathrm{aA}}$ \\
\hline Hardness $(\mathrm{N})$ & $\mathrm{CB}$ & $166.46 \pm 35.91^{\mathrm{aA}}$ & $140.85 \pm 5.47^{\mathrm{aA}}$ & $180.60 \pm 12.01^{\mathrm{aA}}$ \\
\hline \multirow[t]{2}{*}{ Cohesiveness } & CA & $0.74 \pm 0.01^{\mathrm{aA}}$ & $0.61 \pm 0.07^{\mathrm{aB}}$ & $0.34 \pm 0.06^{\mathrm{aC}}$ \\
\hline & $\mathrm{CB}$ & $0.74 \pm 0.01^{\mathrm{aA}}$ & $0.50 \pm 0.03^{\mathrm{aB}}$ & $0.33 \pm 0.02^{\mathrm{aC}}$ \\
\hline \multirow[t]{2}{*}{ Springiness } & $\mathrm{CA}$ & $0.82 \pm 0.02^{\mathrm{bA}}$ & $0.77 \pm 0.03^{\mathrm{aAB}}$ & $0.71 \pm 0.04^{\mathrm{aB}}$ \\
\hline & $\mathrm{CB}$ & $0.88 \pm 0.02^{\mathrm{aA}}$ & $0.73 \pm 0.03^{\mathrm{aB}}$ & $0.70 \pm 0.01^{\mathrm{aB}}$ \\
\hline Cutting-shear $(\mathrm{N})$ & $\mathrm{CB}$ & $4.72 \pm 0.39^{\mathrm{aA}}$ & $2.80 \pm 0.13^{\mathrm{aB}}$ & $4.82 \pm 0.06^{\mathrm{aA}}$ \\
\hline
\end{tabular}

${ }^{\star}$ Results expressed as mean of six replications \pm standard deviation $(\mathrm{n}=12)$. Values with different letters are significantly different $(\mathrm{P}<0.05)$. Lowercase letters in the same column $=$ differences between samples in the same ripening period (Test $\mathrm{t})$. Capital letters in the same row $=$ differences during ripening $($ Tukey test). CA $=$ cheese with autochthonous culture $\mathrm{A} ; \mathrm{CB}=$ cheese with autochthonous culture $\mathrm{B}$.

and remained constant until 120 days (Table 2). This fact is associated to the quantity of dry matter caused by water loss during ripening. The increase of protein and lipid content results in lower light reflection in the product (García-Pérez et al., 2005).

The $\mathrm{a}^{*}$ value for $\mathrm{CB}$ was significantly higher than $\mathrm{CA}$ at 120 days of ripening and increased in the both cheeses during the ripening period $(\mathrm{p}<0.05)$. The CA cheese showed higher yellowness than $\mathrm{CB}$ at 0 and 120 days. Ripening affected $\mathrm{b}^{\star}$ parameters of $\mathrm{CB}$, an increase in yellowness was observed at the end of the ripening period. The milk fat is an important factor that influences the color parameters of cheeses. In fact, $\mathrm{CB}$ has higher lipid content than $\mathrm{CA}$, suggesting that lipid contributes to the yellow color of 
the cheese. Similar results have been reported in previous studies (Todescatto, 2014; Roncatti, 2016). Additionally, in our group (Steinbach et al., 2015), higher yellowness was determined by descriptive sensory analysis for CB cheese (data not shown).

The mean values of textural properties are shown in Table 2. Springiness values of $\mathrm{CA}$ and $\mathrm{CB}$ were significantly different at the beginning of ripening $(p<0.05)$. Interestingly, there was no change in the hardness of cheeses during ripening. Our results are opposite to what has been described for Beyaz cheese. Hardness decreased gradually over the ripening period in this cheese, probably due to the proteolysis process (Guven et al., 2006). Todescatto (2014) reported different observations about Brazilian regional cheese. The author reported an increase in hardness during ripening that was higher than the value found in this study.

Cohesiveness, springiness and chewiness results of CA and $\mathrm{CB}$ cheeses decreased over the ripening period. Chewiness is the strength required to chew solid food; it is a secondary parameter derived from hardness, cohesiveness and springiness results (Tunick, 2000). Cohesion and springiness may have influenced chewiness, since these two parameters also decreased over the ripening of both cheese types.
Results for the cutting-shear tests of CA and CB showed no significant difference between them. At 60 days of ripening the shear values decreased significantly. Making an analogy in sensory terms, the strength required by the incisor teeth to bite the cheese sample was lower, which may have been caused by the hydrolysis of proteins at the start of ripening (McSweeney, 2004). However, at 120 days of ripening the shear strength to bite increased significantly when compared to 60 days. This result can be correlated with the decrease in moisture content and concentration of solids (Beuvier \& Buchin, 2004).

\subsection{Relationship between physical and chemical parameters}

To assess if there is correlation between the chemical composition and the color and texture of the regional cheese, a linear correlation test was performed (Table 3 and Table 4 ). For the $\mathrm{L}^{*}$ coordinate, aw and moisture variables showed positive correlation. The variables lipids, total solids, $\mathrm{SN}-\mathrm{pH} 4.6$ and SN-TCA showed negative correlation. The positive correlation with aw and moisture is explained by the decrease in brightness when there is water loss, which also causes the concentration of solids in the cheese and results in lower light reflection (García-Pérez et al., 2005). The a* coordinate presented correlation with the same variables for the $\mathrm{L}^{*}$ coordinate. Lipids were the only positive correlation for the $\mathrm{b}^{*}$ coordinate. In fact,

Table 3. Pearson correlation coefficients between physicochemical parameters and color of the Brazilian regional cheese.

\begin{tabular}{|c|c|c|c|c|c|c|c|c|c|c|}
\hline & aw & Moisture & Total solids & $\mathrm{TN}$ & Fat & SN-pH 4.6 & SN-TCA & $\mathrm{L}^{*}$ & $a^{*}$ & $b^{*}$ \\
\hline aw & 1 & & & & & & & & & \\
\hline Moisture & $0.933^{\star}$ & 1 & & & & & & & & \\
\hline Total solids & $-0.933^{\star}$ & $-1.000^{*}$ & 1 & & & & & & & \\
\hline $\mathrm{TN}$ & $-0.930^{*}$ & $-0.860^{*}$ & $0.860^{*}$ & 1 & & & & & & \\
\hline Fat & $-0.866^{\star}$ & $-0.978^{\star}$ & $0.978^{*}$ & 0.791 & 1 & & & & & \\
\hline SN-pH 4.6 & $-0.979^{*}$ & $-0.955^{\star}$ & $0.955^{\star}$ & $0.889^{\star}$ & $0.879^{\star}$ & 1 & & & & \\
\hline SN-TCA & $-0.986^{*}$ & $-0.969^{*}$ & $0.969^{*}$ & $0.915^{\star}$ & $0.930^{*}$ & $0.973^{*}$ & 1 & & & \\
\hline $\mathrm{L}^{*}$ & $0.893^{\star}$ & $0.934^{\star}$ & $-0.934^{*}$ & -0.794 & $-0.858^{*}$ & $-0.948^{*}$ & $-0.885^{\star}$ & 1 & & \\
\hline$a^{*}$ & $0.931^{\star}$ & $0.900^{*}$ & $-0.900^{*}$ & -0.766 & $-0.816^{\star}$ & $-0.972^{*}$ & $-0.919^{\star}$ & $0.925^{\star}$ & 1 & \\
\hline$b^{*}$ & -0.480 & -0.733 & 0.733 & 0.316 & $0.818^{\star}$ & 0.548 & 0.580 & -0.659 & -0.552 & 1 \\
\hline
\end{tabular}

${ }^{\star}$ Correlation is significant $(P<0.05) . \mathrm{TN}=$ total nitrogen; $\mathrm{SN}-\mathrm{pH} 4.6=$ soluble nitrogen at $\mathrm{pH} 4.6$; $\mathrm{SN}-\mathrm{TCA}=$ soluble nitrogen at $12 \%(\mathrm{w} / \mathrm{v})$ trichloroacetic acid.

Table 4. Pearson correlation coefficients between physicochemical parameters and textural data of the Brazilian regional cheese.

\begin{tabular}{|c|c|c|c|c|c|c|c|c|c|c|c|c|}
\hline & aw & Moisture & Total solids & $\mathrm{TN}$ & Fat & SN-pH 4.6 & SN-TCA & $\mathrm{H}$ & $\mathrm{C}$ & $\mathrm{S}$ & $\mathrm{CH}$ & $\mathrm{CS}$ \\
\hline aw & 1 & & & & & & & & & & & \\
\hline Moisture & $0.933^{*}$ & 1 & & & & & & & & & & \\
\hline Total solids & $-0.933^{*}$ & $-1.000^{*}$ & 1 & & & & & & & & & \\
\hline $\mathrm{TN}$ & $-0.930^{*}$ & $-0.860^{\star}$ & $0.860^{*}$ & 1 & & & & & & & & \\
\hline Fat & $-0.866^{*}$ & $-0.978^{\star}$ & $0.978^{*}$ & 0.791 & 1 & & & & & & & \\
\hline SN-pH 4.6 & $-0.979^{*}$ & $-0.955^{\star}$ & $0.955^{\star}$ & $0.889^{\star}$ & $0.879^{*}$ & 1 & & & & & & \\
\hline SN-TCA & $-0.986^{*}$ & $-0.969^{\star}$ & $0.969^{*}$ & $0.915^{\star}$ & $0.930^{*}$ & $0.973^{*}$ & 1 & & & & & \\
\hline $\mathrm{H}$ & -0.356 & -0.422 & 0.422 & 0.633 & 0.470 & 0.286 & 0.413 & 1 & & & & \\
\hline $\mathrm{C}$ & $0.960^{*}$ & $0.941^{\star}$ & $-0.941^{\star}$ & $-0.950^{*}$ & $-0.876^{*}$ & $-0.967^{\star}$ & $-0.969^{*}$ & -0.490 & 1 & & & \\
\hline S & $0.927^{\star}$ & $0.934^{\star}$ & $-0.934^{\star}$ & -0.789 & $-0.895^{\star}$ & $-0.954^{\star}$ & $-0.955^{\star}$ & -0.228 & $0.929^{*}$ & 1 & & \\
\hline $\mathrm{CH}$ & $0.955^{\star}$ & $0.936^{*}$ & $-0.936^{\star}$ & $-0.827^{\star}$ & $-0.866^{*}$ & $-0.987^{\star}$ & $-0.958^{\star}$ & -0.198 & $0.946^{*}$ & $0.984^{\star}$ & 1 & \\
\hline CS & 0.192 & 0.199 & -0.199 & 0.093 & -0.097 & -0.325 & -0.141 & 0.748 & 0.105 & 0.305 & 0.379 & 1 \\
\hline
\end{tabular}

${ }^{\star}$ Correlation is significant $(P<0.05) . \mathrm{H}=$ Hardness; $\mathrm{C}=$ Cohesiveness; $\mathrm{S}=$ Springiness; $\mathrm{CH}=$ Chewiness; $\mathrm{CS}=\mathrm{Cutting}$-shear; TN = total nitrogen; $\mathrm{SN}$-pH $4.6=$ soluble nitrogen at $\mathrm{pH}$ 4.6; SN-TCA = soluble nitrogen at $12 \%(\mathrm{w} / \mathrm{v})$ trichloroacetic acid. 
the increase in lipid content increases the $b^{\star}$ coordinate values, i.e., the cheese becomes more yellow.

Hardness and chewiness showed no correlation with any of the evaluated parameters (Table 4). For Parmesan-type cheese, a negative correlation was observed between hardness and water activity (Jaster et al., 2014). Cohesiveness, springiness and chewiness showed positive correlation to the aw and moisture variables, i.e., as the aw and moisture decreased the mentioned texture attributes also decreased. The same texture attributes showed negative correlation with the variables total solids, protein (except for springiness), lipids, SN-pH 4.6 and SN-TCA; during ripening the concentration of total solids, protein, lipids and increase of proteolysis rates occurred, consequently reducing the texture attributes. Thus, it is confirmed that the proteolysis and the decrease in water activity as a result of the concentration of solids during ripening have significant influence on regional cheese texture (Beuvier \& Buchin, 2004; McSweeney, 2004).

Complementary studies should be made in the future to go further into the knowledge about others chemical parameters (volatile compounds, peptides) and sensory characterization (Soares et al., 2017; Sperry et al., 2018). In fact, sensory characteristics define the acceptance of cheese by consumers and could help to identify the markers of product quality (Bemfeito et al., 2016). For this, temporal and projective methods associated with acceptance tests can promote additionally information about Brazilian regional cheeses.

\section{Conclusion}

The regional cheese presented decrease in luminosity and increase in green and yellow color during ripening, being commonly characterized as a light and yellow-colored cheese. The linear correlation test showed that the chemical parameters: aw, moisture, total solids, protein, lipids, SN-pH 4.6 and SN-TCA influenced its color and texture characteristics. The characterization of this cheese, together with the appeal of using a typical culture of a region, can help in the process of Geographical Indication for Brazilian regional cheese. Additionally, the uses of autochthonous cultures could have a strong influence on the economy of the region.

\section{Acknowledgements}

This work was supported by Laticínios Soberano and Agência de Desenvolvimento Regional do Sudoeste do Paraná. The authors gratefully thank the Laticínios Primo Queijo for the support.

\section{References}

American Public Health Association - APHA. (2004). Standard methods for the microbiological examination of foods. Washington: APHA.

Association of Official Analytical Chemists - AOAC. (2005). Official methods of analysis (18th ed.). Gaithersburg: AOAC International.

Barros, J. J. C., Azevedo, A. C., Faleiros, L. R. Jr., Taboga, S. R., \& Penna, A. L. B. (2011). Parmesan cheese: physicochemical and microbiological quality and microstructure. Food Science and Technology, 31(2), 285-294. http://dx.doi.org/10.1590/S0101-20612011000200002.
Batista, A. L. D., Silva, R., Cappato, L. P., Ferreira, M. V. S., Nascimento, K. O., Schmiele, M., Esmerino, E. A., Balthazar, C. F., Silva, H. L. A., Moraes, J., Pimentel, T. C., Freitas, M. Q., Raices, R. S. L., Silva, M. C., \& Cruz, A. G. (2017). Developing a synbiotic fermented milk using probiotic bacteria and organic green banana flour. Journal of Functional Foods, 38, 242-250. http://dx.doi.org/10.1016/j. jff.2017.09.037.

Bemfeito, R. M., Rodrigues, J. F., Silva, J. G., \& Abreu, L. R. (2016). Temporal dominance of sensations sensory profile and drivers of liking of artisanal Minas cheese produced in the region of Serra da Canastra, Brazil. Journal of Dairy Science, 99(10), 7886-7897. http:// dx.doi.org/10.3168/jds.2016-11056. PMid:27497904.

Beresford, T. P., Fitzsimons, N. A., Brennan, N. L., \& Cogan, T. M. (2001). Recent advances in cheese microbiology. International Dairy Journal, 11(4-7), 259-274. http://dx.doi.org/10.1016/S0958-6946(01)00056-5.

Beuvier, E., \& Buchin, S. (2004). Raw milk cheeses. In P. Fox, P. McSweeney, T. Cogan \& T. Guinee (Eds.), Cheese: chemistry, physics and microbiology (pp. 319-346). London: Academic Press. http:// dx.doi.org/10.1016/S1874-558X(04)80072-1.

Bontinis, T. G., Mallatou, H., Alichanidis, E., Kakouri, A., \& Samelis, J. (2008). Physicochemical, microbiological and sensory changes during ripening and storage of Xinotyri, a traditional Greek cheese from raw goat's milk. International Journal of Dairy Technology, 61(3), 229-236. http://dx.doi.org/10.1111/j.1471-0307.2008.00404.x.

Brasil. (1996, March 11). Aprova os regulamentos técnicos de identidade e qualidade dos produtos lácteos (Portaria n 146, de 7 março de 1996). Diário Oficial [da] República Federativa do Brasil.

Câmara, S. P. A., Dapkevicius, A., Rosa, H. J. D., Silva, C. C. G., Malcata, F. X., \& Enes Dapkevicius, M. L. N. (2017). Physicochemical, biochemical, microbiological and safety aspects of Pico cheese: assessment throughout maturation and on the final product. International Journal of Dairy Technology, 70(4), 542-555. http:// dx.doi.org/10.1111/1471-0307.12424.

Castro-Cislaghi, F. P., \& Badaró, A. C. L. (2019). Segurança alimentar na produção de queijos: queijo colonial artesanal. Francisco Beltrão: Grafisul. Retrieved from http://leite.fb.utfpr.edu.br

Cichoscki, A. J., Valduga, E., Valduga, A. T., Tornadijo, M. E., \& Fresno, J. M. (2002). Characterization of Prato cheese, a Brazilian semi-hard cow variety: evolution of physico-chemical parameters and mineral composition during ripening. Food Control, 13(4-5), 329-336. http:// dx.doi.org/10.1016/S0956-7135(02)00039-7.

Food and Agriculture Organization - FAO, World Health Organization - WHO. (2011). Codex alimentarius: milk and milk products. Rome: FAO. Retrieved from http://www.fao.org/3/a-i2085e.pdf

Food and Agriculture Organization - FAO, FAOSTAT. (2016). Statistical database of the food and agriculture organization of the United Nations. Rome: FAO. Retrieved from http://www.faostat.fao.org

Garcia, G. A. C., Moretti, B. R., Gomes, R. G., Casarotti, S. N., \& Penna, A. L. B. (2009). Composition of macronutrients and evolution of ripening of low fat Prato cheese with the addition of the proteolytic enzyme fastuosain. In VII Brazilian Meeting on Chemistry of Food and Beverages (BMCFB) (pp. 69-77). Lorena, SP: EEL-USP.

García-Pérez, F. J., Lario, Y., Fernández-López, J., Sayas, E., PérezalVarez, J. A., \& Sendra, E. (2005). Effect of orange fiber addition on yogurt color during fermentation and cold storage. Color Research and Application, 30(6), 457-463. http://dx.doi.org/10.1002/col.20158.

González-Córdova, A. F., Yescas, C., Ortiz-Estrada, A. M., De la RosaAlcaraz, M. A., Hernández-Mendoza, A., \& Vallejo-Cordoba, B. (2016). Artisanal Mexican cheeses. Journal of Dairy Science, 99(5), 3250-3262. http://dx.doi.org/10.3168/jds.2015-10103. PMid:26830738. 
Guven, M., Yerlikaya, U. S., \& Hayaloglu, A. A. (2006). Influence of salt concentration on the characteristics of Beyaz cheese, a Turkish white-brined cheese. Le Lait, 86(1), 73-81. http://dx.doi.org/10.1051/ lait:2005043.

Jaster, H., Campos, A. C. L. P., Auer, L. B., Los, F. G. B., Salem, R. D. S., Esmerino, L. A., Nogueira, A., \& Demiate, I. M. (2014). Quality evaluation of parmesan-type cheese: a chemometric approach. Food Science and Technology, 34(1), 181-188. http://dx.doi.org/10.1590/ S0101-20612014000100026.

Johnson, M. E. (2017). A 100-year review: cheese production and quality. Journal of Dairy Science, 100(12), 9952-9965. http://dx.doi. org/10.3168/jds.2017-12979. PMid:29153182.

Kamimura, B. A., Magnani, M., Luciano, W. A., Campagnollo, F. B., Pimentel, T. C., Alvarenga, V. O., Pelegrino, B. O., Cruz, A. G., \& Sant'Ana, A. S. (2019). Brazilian artisanal cheeses: an overview of their characteristics, main types and regulatory aspects. Comprehensive Reviews in Food Science and Food Safety, 18(5), 1636-1657. http:// dx.doi.org/10.1111/1541-4337.12486.

McSweeney, P. L. H. (2004). Biochemistry of cheese ripening. International Journal of Dairy Technology, 57(2-3), 127-144. http:// dx.doi.org/10.1111/j.1471-0307.2004.00147.x.

Pedersen, T. B., Vogensen, F. K., \& Ardo, Y. (2016). Effect of heterofermentative lactic acid bacteria of DL-starters in initial ripening of semi-hard cheese. International Dairy Journal, 57, 7279. http://dx.doi.org/10.1016/j.idairyj.2016.02.041.

Pereira, E. A., Roncatti, R., Todescatto, C., Beux, S., Marchi, J. F., \& Daltoé, M. L. M. (2017). Acceptance of Santo Giorno cheese typical of the Southwestern region of Paraná, Brazil. Ciência Rural, 47(4), 1-8. http://dx.doi.org/10.1590/0103-8478cr20160418.

Roncatti, R. (2016). Desenvolvimento e caracterização do queijo Santo Giorno, típico do sudoeste do Paraná, produzido com leite cru e fermento endógeno. (Dissertação de mestrado). Universidade Tecnológica Federal do Paraná, Pato Branco.

Sant'Anna, F. M., Acurcio, L. B., Alvim, L. B., Castro, R. D., Oliveira, L. G., Silva, A. M., Nunes, A. C., Nicoli, J. R., \& Souza, M. R. (2017). Assessment of the probiotic potential of lactic acid bacteria isolated from Minas artisanal cheese produced in the Campo das Vertentes region, Brazil. International Journal of Dairy Technology, 70(4), 592601. http://dx.doi.org/10.1111/1471-0307.12422.

Soares, E. K. B., Esmerino, E. A., Ferreira, M. V. S., Silva, M. A. A. P., Freitas, M. Q., \& Cruz, A. G. (2017). What are the cultural effects on consumers' perceptions? A case study covering coalho cheese in the Brazilian northeast and southeast area using word association. Food
Research International, 102, 553-558. http://dx.doi.org/10.1016/j. foodres.2017.08.053. PMid:29195985.

Sperry, M. F., Silva, H. L. A., Balthazar, C. F., Esmerino, E. A., Verruck, S., Prudencio, E. S., Cucinelli, R. P. No., Tavares, M. I. B., Peixoto, J. C., Nazzaro, F., Rocha, R. S., Moraes, J., Gomes, A. S. G., Raices, R. S. L., Silva, M. C., Granato, D., Pimentel, T. C., Freitas, M. Q., \& Cruz, A. G. (2018). Probiotic Minas Frescal cheese added with L. casei 01: physicochemical and bioactivity characterization and effects on hematological/biochemical parameters of hypertensive overweighted women: a randomized doubleblind pilot trial. Journal of Functional Foods, 45, 435-443. http://dx.doi.org/10.1016/j.jff.2018.04.015.

Steinbach, J., Burgardt, V. C. F., Machado, A., Marchi, J., Quevedo, C. C., Becker, J., \& Badaró, A. C. L. (2015). Perfil sensorial do queijo Santo Giorno. In Anais do III Workshop de Ciência, Tecnologia e Inovação. Francisco Beltrão: UTFPR. Retrieved from https://wcti. fb.utfpr.edu.br/2015/anais/anaiswcti2015.pdf

Tamime, A. Y. (2006). Fermented milks. Oxford: Blackwell Science. http://dx.doi.org/10.1002/9780470995501.

Todescatto, C. (2014). Obtenção de fermento lático endógeno para a produção de queijo típico da mesorregião sudoeste do Paraná (Dissertação de mestrado). Universidade Tecnológica Federal do Paraná, Pato Branco.

Tonial, I. B., Bravo, C. E. C., Souza, N. E., Matsushita, M., Furuya, W. M., \& Visentainer, J. V. (2011). Qualidade nutricional dos lipídios de tilápias (Oreochromis niloticus) alimentadas com ração suplementada com óleo de soja. Alimentos e Nutrição, 22(1), 103-112.

Tunick, M. H. (2000). Rheology of dairy foods that gel, stretch and fracture. Journal of Dairy Science, 83(8), 1892-1898. http://dx.doi. org/10.3168/jds.S0022-0302(00)75062-4. PMid:10984168.

Turan, H., Sönmez, G., \& Kaya, Y. (2007). Fatty acid profile and proximate composition of the thornback ray (Raja clavata, L. 1758) from the Sinop coast in the Black Sea. Journal Fisheries Science, 1(2), 97-103. http://dx.doi.org/10.3153/jfscom.2007012.

Vasek, O. M., Mazza, S. M., \& Giori, G. S. (2013). Physicochemical and microbiological evaluation of corrientes artisanal cheese during ripening. Food Science and Technology, 33(1), 151-160. http://dx.doi. org/10.1590/S0101-20612013005000021.

Wolf, I. V., Perotti, M. C., Bernal, S. M., \& Zalazar, C. A. (2010). Study of the chemical composition, proteolysis, lipolysis and volatile compounds profile of commercial Reggianito Argentino cheese: characterization of Reggianito Argentino cheese. Food Research International, 43(4), 1204-1211. http://dx.doi.org/10.1016/j. foodres.2010.02.018. 